\title{
Detecção de allexivírus em primórdios foliares de alho via RT-PCR
}

\author{
Robson José do Nascimento ${ }^{1,3}$, Gilvan Pio-Ribeiro ${ }^{1}$, Roseane Cavalcanti dos Santos ${ }^{2}$, \\ Péricles de Albuquerque Melo Filho ${ }^{1}$
}

${ }^{1}$ Departamento de Agronomia, Universidade Federal Rural de Pernambuco, CEP 52171-900, Recife, PE. E-mail: pericles@ depa.ufrpe.br; ${ }^{2}$ Embrapa Algodão; ${ }^{3}$ Bolsista do CNPq.

Autor para correspondência: Péricles de Albuquerque Melo Filho. pericles@ depa.ufrpe.br

Data de chegada: 21/03/2006. Aceito para publicação em: 06/11/2008

\section{RESUMO}

Nascimento, R.J.; Pio-Ribeiro, G.; Santos, R.C.; Melo Filho, P. A. Detecção de allexivírus em primórdios foliares de alho via RT-PCR. Summa Phytopathologica, v.34, n.3, p.267-299, 2008

Nos procedimentos de detecção de allexivirus em bulbos de alho, tem-se como rotina o plantio de bulbilhos para obtenção de tecido foliar a ser analisado via testes sorológicos e/ou moleculares. A disponibilização das plantas em casa de vegetação implica em gastos com a manutenção e requer, em média, 30 dias. Em áreas isentas desses vírus, corre-se, ainda, o risco de sua introdução e disseminação. No presente trabalho buscou-se ajustar um protocolo para detecção rápida de allexivírus em alho a partir de primórdios foliares. Bulbilhos de alho para consumo, oriundos do Rio Grande do Sul e importados da Argentina foram dissecados para obtenção de primórdios foliares e extração de RNA total a partir de $0,1 \mathrm{~g}$ de tecido. A seguir foram conduzidas reações de RT-PCR com um par de oligonucleotídeos, capaz de gerar um fragmento de aproximadamente 500 pb relativo à porção interna do gene da capa protéica de várias espécies do gênero Allexivirus. Uma banda com tamanho aproximado de 500 pb foi visualizada, em gel de agarose e, posteriormente, confirmada por Southern Blot e por seqüenciamento como sendo Garlic vírus C (GarV-C, AY170322.1). A obtenção de RNA total diretamente de primórdios foliares de bulbilhos e seu uso em análise de RT-PCR, constituem-se em uma metodologia econômica, rápida e segura para a detecção de allexivírus em bulbos de alho.

Palavras chave adicionais: Allium sativum, alexiviroses, Southern Blot, RT-PCR.

\section{ABSTRACT}

Nascimento, R.J.; Pio-Ribeiro, G.; Santos, R.C.; Melo Filho, P.A. Detection of allexivírus on primordial garlic leaves using RT-PCR. Summa Phytopathologica, v.34, n.3, p.267-269, 2008

Cloves crop is a routinely practice often used in procedures for detecting allexiviruses in garlic bulbs to obtainment foliar tissue to be analyzed by serological and/or molecular tests. The availability of the plants under greenhouse implies is expenses with the maintenance and requires abaut 30 days. In areas free of these viruses, there is also the risk of their introduction and dissemination. This study presents an adjustment of protocol aiming a fast detection of allexiviruses, using primordial leaves. Cloves of consumptiongarlic, from Rio Grande do Sul, Brazil, and imported from Argentina were dissected for obtaining primordial leaves and total
RNA extraction, using $0,1 \mathrm{~g}$ of tissue of each sample. RT-PCR reactions were performed with a pair of primers able to amplify a $500 \mathrm{bp}$ fragment, corresponding to the internal region of the coat protein gene from several species of Allexivirus genus. A band in the expected height $(500 \mathrm{pb})$ was visualized in agarose gels and further confirmed using Southern Blot test and by sequencing as Garlic virus C (GarV-C, AY170322.1). Total RNA obtained from foliar primordia of cloves and its use in RT-PCR analysis is an economic, fast and secure methodology for allexivirus detection in garlic bulbs.

Addtional keywords: Allium sativum, allexiviruses, Southern Blot, RT-PCR.

O alho é hospedeiro natural de espécies de allexivírus. Entre as espécies recentemente detectadas no Brasil, encontram-se: Garlic virus A (GarV-A), Garlic virus B (GarV-B), Garlic virus C (GarV-C), Garlic virus D (GarV-D) e Garlic mite-borne filamentous virus (GarMbFV) (6). Garlic virus E (GarV-E), Garlic virus X (GarV-X) e Shallot virus $X(\mathrm{ShV}-\mathrm{X})$ ainda não foram detectadas no país (6). A detecção de vírus de alho tradicionalmente tem sido realizada via testes sorológicos (3). Para tanto se faz necessário a obtenção de tecido foliar com alta concentração de partículas virais. Isso é obtido por prévia brotação de bulbilhos, que dura cerca de 30 dias. O presente trabalho teve por objetivo ajustar um protocolo para detecção de allexivírus, a partir de primórdios foliares coletados de bulbilhos infectados, de modo a reduzir o tempo de análise de detecção desses vírus.

Bulbos de alho nobre oriundos do Rio Grande do Sul e da Argentina foram coletados na Central de Abastecimento do Estado de Pernambuco (CEAGEPE). De cada amostra foram coletados $0,1 \mathrm{~g}$ de tecido do primórdio foliar, retirado via dissecação de bulbilhos (Figura 1A) e empregado para extração de RNA total, utilizando o reagente 
A

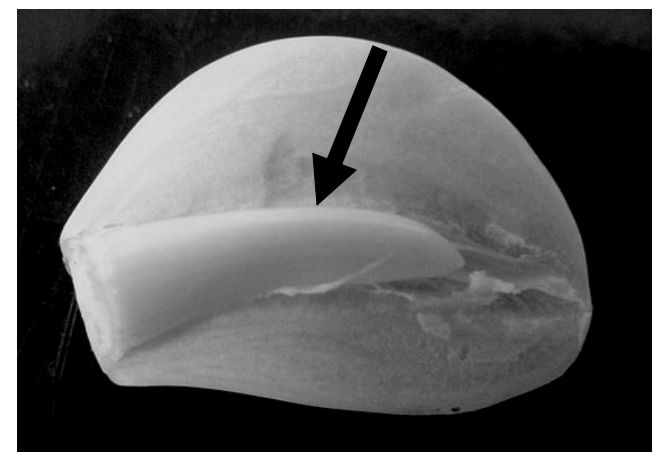

B



M RS AG RS AG
C



Figura 1. (A)-Detalhe de um bulbilho de alho dissecado, apresentando o primórdio foliar (seta); (B)- Produtos de RTPCR em gel de agarose $(0,8 \%)$, obtidos de RNA total extraído de bulbilho de alho, (M- 1 Kb Plus DNA Ladder (Invitrogen), RS-Rio Grande do Sul, AG-Argentina); (C) - Membrana obtida a partir de Southern Blot com sinal positivo para as respectivas análises de PCR.

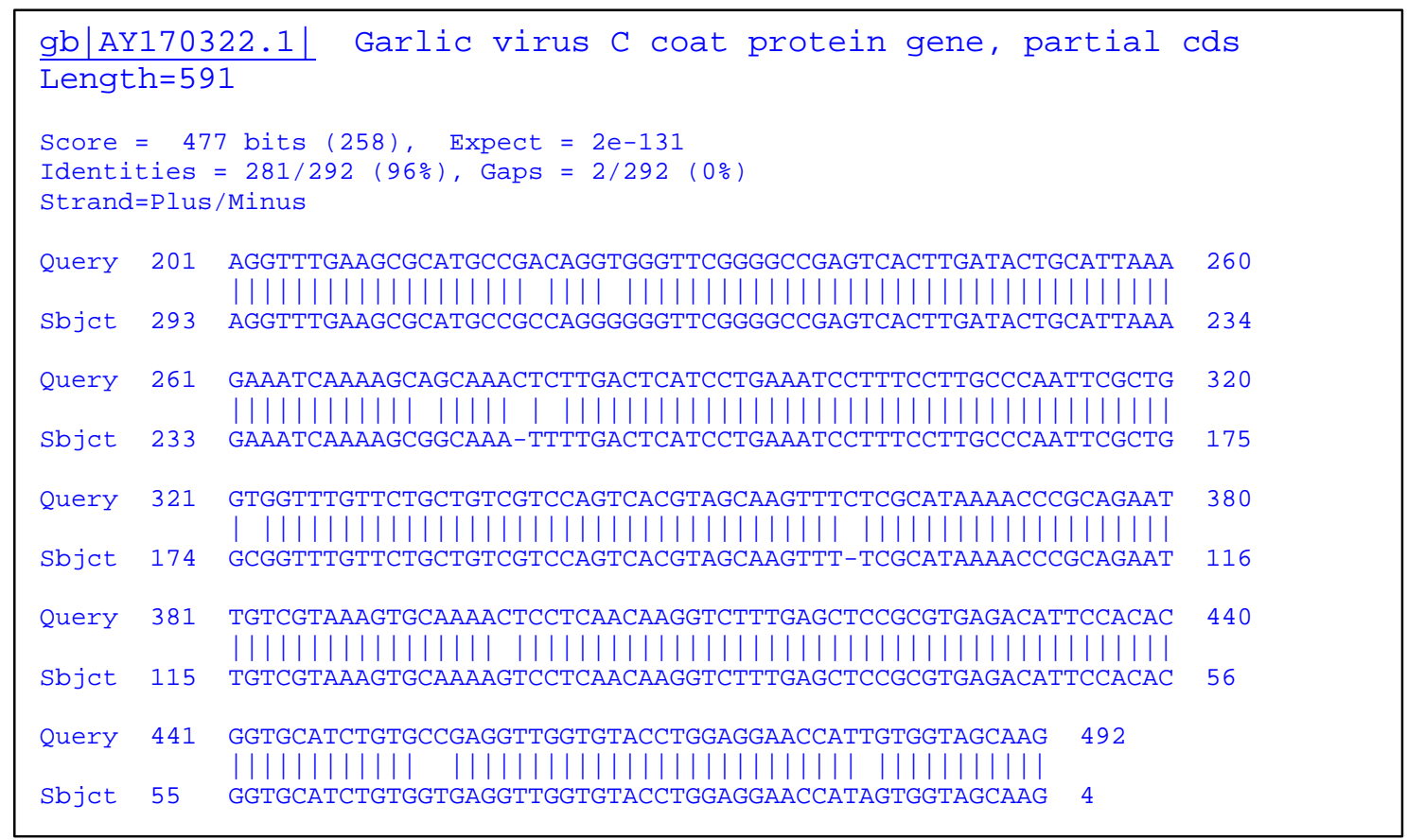

Figura 2 Alinhamento da seqüência de nucleotídeos da capa protéica do isolados de Garlic virus $C$ (GarV-C), encontrado no Rio Grande do Sul e o acesso obtido do GenBank (Acesso AY170322.1).

Trizol (Invitrogen), segundo recomendações do fabricante. As reações de RT-PCR seguiram-se como descrito em Nascimento (4), onde se utilizou oligonucleotídeos capazes de anelar internamente na ORF da capa protéica de GarV-A, GarV-B, GarV-C, GarV-D e GarMbFV. As condições de PCR utilizadas foram: um ciclo de desnaturação a $95^{\circ} \mathrm{C} / 5 \mathrm{~min}, 40$ ciclos de desnaturação a $94{ }^{\circ} \mathrm{C} / 1 \mathrm{~min}$, anelamento a $53{ }^{\circ} \mathrm{C} / 1$ min e extensão a $72{ }^{\circ} \mathrm{C} / 1$ min e 30 seg e um ciclo final de extensão a $72{ }^{\circ} \mathrm{C} / 5 \mathrm{~min}$. Os produtos desta reação foram analisados em gel de agarose $(0.8 \%)$ e posteriormente transferidos para uma membrana (Hybond-N-Nylon, Amersham Life Science ${ }^{\circledR}$ ) para teste de Southern Blot com sonda fria. A sonda empregada refere-se a um fragmento de $752 \mathrm{pb}$ do gene da capa protéica de GarV-C, produzido por Melo Filho (6) que empregou um par oligonucleotídeos específicos para esta espécie. Para marcação da sonda, utilizou-se o kit "Dig DNA Labeling and Detection" (Roche), onde o DNA foi marcado com digoxigenina e a revelação procedida com uma mistura de sais BICP/ NBT. Para confirmação da espécie viral, o fragmento obtido a partir da amostra do Rio Grande do Sul foi seqüenciado no MegaBASE (GE) do Laboratório Genoma da UFRPE, utilizando o kit LPA Dynamic Terminator, seguindo recomendações do fabricante. As seqüências obtidas foram editadas no programa Chromas 2.3 (MCF Aplication) e em seguida realizado comparação da seqüência por meio da ferramenta BlastN do National Center for Biotecnology Information - NCBI (http//www.ncbi.nih.nlm.gov).

$O$ produto de PCR, gerado a partir de RNA total obtido de primórdios foliares de bulbilhos dissecados, apresentou uma banda 
próxima a $500 \mathrm{pb}$, conforme esperado, demonstrando a infecção por allexivírus nas amostras oriundas do Rio Grande do Sul e da Argentina (Figura 1B). Isto está em consonância com Melo Filho (6), demonstrando a confiabilidade do teste e indicando aplicabilidade desta metodologia, que possibilitou a obtenção de resultados semelhante aos descritos na literatura $(1,2)$, obtidos com procedimentos mais trabalhosos. O teste de Southern Blot, também confirmou a infecção por allexivírus, nas duas amostras testadas (Figura 1C) e está de acordo com os resultados obtidos por Melo Filho (6). A análise do fragmento seqüenciado, obtido a partir da amostra de alho originária do Rio Grande do Sul, apresentou identidade de $96 \%$ com o gene da capa protéica de GarV-C (E-value: 2e-131), (Figura 2).

A extração de RNA total diretamente dos primórdios foliares destaca-se como o elemento principal da presente metodologia, a qual permitiu o fornecimento de quantidade de ácido nucléico viral suficiente para a realização de transcrição reversa e amplificação do fragmento genômico alvo. Essa metodologia apresenta praticidade e rapidez, possibilitando a obtenção dos resultados em até $48 \mathrm{~h}$. Ao mesmo tempo a metodologia caracteriza-se como uma alternativa mais segura para a detecção de vírus em alho, visto que nos procedimentos descritos na literatura $(2,5)$, faz-se necessário a previa brotação dos bulbilhos, por um período médio de 30 dias. Durante este período, a exposição das plantas de alho em crescimento, potencializa a disseminação desses agentes virais presente nos materiais a serem testados, via ação de ácaros vetores. O método apresenta ainda a possibilidade de ser adaptado para uso em procedimentos quarentenários, visando à detecção de outras espécies de vírus de alho, tais como: Onion yellow dwarf virus (OYDV) e Leek yellow stripe virus (LYSV), pela simples utilização de oligonucleotídeos específicos e com isso, reduzir ainda mais o período de retenção do produto nos portos e principalmente, os custos alfandegários.

\section{REFERÊNCIAS BILBIOGRÁFICAS}

1. Chen, J.; Zheng, H.Y.; Antoniw, J.F.; ADAMS, M.J.; Chen, J.P.; Lin, L. Detection and classification of allexiviruses from garlic in China. Archives of Virology, New York, v.149, n.3, p.435445, 2004.

2. Dovas, C.I.; Hatziloukas, E.; Salomon, R.; Barg, E.; Shiboleth, Y.; Katis, N.I. Comparison of methods for virus detection in Allium spp. Journal of Phytopathology, Berlin, v.149, n.11, p.731737, 2001.

3. Dusi, A.N. Doenças causadas por vírus em alho. Informe Agropecuário, Belo Horizonte, v.17, n. 183, p.19-21,1995.

4. Nascimento, R.J. Análise molecular em alho consume nacional e importado para detecção da presença de allexivirus. 2006. 53 f. Dissertação (Mestrado em Fossanidade) - Universidade Federal Rural de Pernambuco, Recife.

5. Melo Filho, P.A.; Nagata, T.; Dusi, A.N.; Buso, J.A.; Torres, A.C.; Eiras, M.; Resende, R.O. Detection of three allexivirus species infecting garlic in Brazil. Pesquisa Agropecuária Brasileira, Brasília, v.39, n.8, p.735-740, 2004.

6. Melo Filho, P.A. Detecção e caracterização molecular de allexivirus e estudo de degenerescência em plantas de alho (Allium sativum L.) provocada por vírus. 2003.118f. Tese (Doutorado em Fitopatologia) - Faculdade de Agronomia, Universidade de Brasília, Brasília. 